\title{
INDIGENOUS VILLAGE GOVERNANCE: LESSONS FROM INDONESIA
}

\author{
Jayadi Nas \\ Associate Professor at the Department \\ of Government, Hasanuddin University. \\ Address: Jl. Perintis Kemerdekaan Km. 10, \\ 90245 Makassar, South Sulawesi, Indonesia. \\ E-mail: jayadi.nas@unhas.ac.id
}

\section{Nurlinah}

Associate Professor at the Department of Government, Hasanuddin University. Address: Jl. Perintis Kemerdekaan Km. 10, 90245 Makassar, South Sulawesi, Indonesia. E-mail: nurlinah@unhas.ac.id

\section{Haryanto*}

Lecturer at the Department of Political Science, Hasanuddin University. Address: Jl. Perintis Kemerdekaan Km. 10, 90245 Makassar, South Sulawesi, Indonesia. E-mail: harymusi@unhas.ac.id

* Corresponding author.

\begin{abstract}
This article explores the model of indigenous village governance as an approach to determine locality value adopted. This approach was chosen in order to criticize the concept of governance which has so far neglected the value of locality that exists in society. This research uses the qualitative method while analyzing the individual and social relationships of people living in Tanah Toa, Indonesia. The research focus is on indigenous governance actors, processes, and regulations. The result shows that Tanah Toa runs the governance with locality value based on three aspects. The first consists of civil society groups while neglecting partners such as market and state. The second focuses on determining whether service delivery to the community is more inclusive, isolated and not integrated with the modern government system. Thirdly, it is self-regulatory, with the rule that runs in government initiated by the community.
\end{abstract}

Keywords: indigenous governance; indigenous village; rural politics; Indonesia.

Citation: Nas, J., Nurlinah \& Haryanto (2019). Indigenous Village Governance: Lessons from Indonesia. Public Administration Issue, no 6, (Special Issue II, electronic edition), pp. 94-104 (in English); DOI: 10.17323/1999-5431-2019-0-6-94-104. 


\section{Introduction}

This article discusses the current practice of indigenous governance in a decentralized village autonomy in Indonesia. We explore how relationships are developed between government actors using its processes and arrangements. The argument is to determine if decentralization has an impact on people living in rural areas. Our primary goal is to find a model that can reconcile local values with modernity of government and which is oriented towards the service and welfare of indigenous people. Village autonomy through Law no. 6/2014 (village law) has led to a new mechanism for governance at the rural level. This law became the legal protection for financial assistance for villages, which, on an individual level, provides space for more autonomous governance of village administrations (Antlöv et al., 2016; Salim et al., 2017; Susan \& Budirahayu, 2018).

However, at the same time, the autonomy triggered a surge in the emergence of indigenous peoples. The demand for immediate recognition is one of the reasons for continuous movement along with the extended autonomy gained by the village. This is not only at the formal level, but an acknowledgment proved by granting rural village rights, including the provision of free spaces to manage assets based on customary rules or adat (Djaha and Lake, 2018; Steenbergen, 2016; Tyson, 2011). This is as the antithesis of the situation controlled by the centralized government system. During this period, indigenous people tend to be tamed by the tight enforcement of political control (Benda-Beckmann and BendaBeckmann, 2010). The community's rights are insufficient. Therefore it is rare for any kind of protest to come from these sets of people aside from demands which happen to be very sporadic in practice and initiated by the village government. This problem became more complicated after 1998; the wave of democratization influenced rural administration. The governance that emerged as a multi-stakeholder was believed to have been able to negotiate many interests, including those of the indigenous people. However, the reverse was the case. Instead of creating a platform for negotiation, governance closes it, making it an element that should be considered in multi-stakeholder schemes.

Unfortunately, the phenomenon of adat government disparity in dealing with village decentralization has not attracted the attention of scholars, with research limited to looking at aspects of local wisdom (Sukmawati et al., 2015; Syarif et al., 2016). Scholars are more focused on issues relating to local wisdom and today indigenous people are one of the social communities with strong local wisdom. This conclusion comes from the analysis building which positioned local wisdom as a domain that became the distinction between indigenous people and others.

Meanwhile, other scholars have also explained rural cultural issues concerning strengthening the existence of indigenous people by presenting local culture as an identity faced with modernization (Kurniawan, 2017; Sastrawati, 2017). These sets of people are scared that someday the local culture will go extinct, and this is one of the major concerns of researchers in this study. Therefore, the ongoing narrative is the matter of how local culture can co-exist with the dynamics of modern society. 
Traditional knowledge of local wisdom is also a theme often used as the focus of research by scholars. Some researchers argue that indigenous people are those with sufficient traditional knowledge compared to the general population (Akifah \& Mukrimin, 2012; Surtikanti et al., 2017). For this reason, traditional knowledge becomes an inherent feature of these sets of people, which in some not only characterizes them but in their daily life, it becomes precious capital, especially in the utilization and processing of forests.

The last focus observed by many researchers on indigenous people is institutionalization. The central question that sets the stage for this issue is how institutional relationships take place in rural areas. Research in this camp includes that conducted by Hidayat, Febriyanto and Nadzir (2017), which focuses on the idea of the institutional strengthening of indigenous people. According to them, today's context requires institutionalization because one of the problems that has been faced by these sets of people is institutional dualism which has the potential to spark conflicts.

In general, previous researchers have agreed that indigenous people are those with characteristics which are different from the general public. Consequently, more studies have focused on their uniqueness but are still lacking in constructing a theoretical argument, thereby creating a gap owing to the limited scope of previous research. Furthermore, no further investigation has been carried out on the uniqueness of rural people and its transformation into the governance system in Indonesia. This is the primary purpose of our research, as will be explained in subsequent sections.

\section{Materials and Methods}

This research was conducted in Ammatoa, Tanah Toa village in Bulukumba district, located approximately $200 \mathrm{~km}$ from the capital of South Sulawesi Province, Indonesia. This village was chosen because it is the only remaining indigenous village in South Sulawesi Province. Certainly, the durability of an indigenous village in Indonesia is very interesting to study, particularly amid the onslaught of development in third world countries. In addition to this, up until 2017, 133 indigenous villages had been established through regional legal products in Indonesia.

By using the descriptive qualitative method, data collection was conducted by observation and by interviewing community leaders in Ammatoa, with field research carried out between March and September 2018. Among those interviewed were the head of Tanah Toa village, the priest (imam) and several community leaders who live within the Ammatoa community, and 43 people of various social statuses were successfully interviewed with several key questions asked based on the research components method. The main question was to determine the system and model of Ammatoa indigenous governance, followed by questions on the indigenous services that take place in the village. The aim is to unravel various case studies of community service and their implications for rural governance. The final question was on factors that support and hinder the governance of services. This question helps to explain the challenges faced in serving the community, as well as the opportunities they pos- 
sess. In this study, two units of analysis were used, namely the individual and the event analysis units. The main unit of analysis in terms of research informants was in three parts: the first was on the lowest, the second the intermediates, namely the village government apparatus, and lastly the top informants, such as indigenous community leaders, academics and historians. To maintain information competitiveness, the informants were chosen based on adequate political, cultural and historical knowledge of the cases studied, as well as emotional and social closeness.

Furthermore, events, such as the results of village elections, government services, networks of organizations, and a wide variety of events that occur in indigenous communities were examined. The data obtained from interviews and explorations of literature were also studied through direct and field observations. This is one way of connecting the relationship between information and the apparent socio-political reality by seeing, listening and feeling what is happening; where, when, who is involved; and how it takes place.

Indigenous village governance in Indonesia has yet to familiarize itself with the concept of indigenous village governance as a technique that focuses on social capital. Scholars trace the concept of social capital as linking the character of various local communities in implementing empowerment and development activities (Field, 2017). The argument built is the value of trust in society about social relations (Carroll, 2009), although it must deal with a pattern of clientelism that is rooted in village communities (Haryanto, 2017). In the case of Sumatra, for example, the indigenous village is more meaningful as a cross-linkage of religious leaders who coincidentally share the same profession (Asrinaldi, 2017, p. 57). Traditional authorities establish this relationship in the form of an unwritten law as a traditional institution that legalizes community faith, which is then strengthened by the legitimacy of the local government in the form of regulations. The three components are community faith, traditional authority, and the legitimacy of the local government, which in turn sustains the Minangkabau community, West Sumatra. Asrinaldi (2017) affirms that the ties between professions rooted for decades do not simply stop at beliefs. Moreover, this association of professions as a bridge is believed to unite the community, including political attitudes. Asrinaldi's credibility is based on reading the value of locality as a more straightforward discipline of political attitudes while ignoring the potential for conflict in the community.

Likewise in some other areas such as in Yogyakarta, social capital is believed to be in the rural village (Humaeni, 2014). These researchers see it as rooted in society as a unity of belief that has grown and embedded for a long time. Furthermore, this belief will become a binding norm in a society that embodies the form of informal institutions and non-governmental organizations. In an informal institution, the only thing that makes people survive is trust. This relationship will last long enough to then create a social network for the community. In Yogyakarta, social capital is used to support development at the village level.

Meanwhile, in Papua social capital is a hallmark of the locality which in practice is more widely used for networking by local actors to minimize conflict amongst communities during elections (Pamungkas, 2017, p. 147). Unfortunately, 
conflict cannot be stopped by local governments, even when using state authority. However, among the friction that occurs, there is a gap capable of minimizing conflict which the people of Papua still believe comes from the customary land. However, community pluralism has become the entrance to social capital as an effort to reduce conflict. The trick is that people are gathered based on the categorization of adat. With customary background similarities, communities will be more easily assembled within a traditional institution. Moreover, the conflict is then mitigated by utilizing key actors in each traditional indigenous institution to discipline the community.

In subsequent developments, social capital gained greater space in governance, especially when the concept opened up space for the involvement of many actors, including civil society. However, regarding the next question on "ways to unite the clashing interests of civil society", social capital is used as a representation of a plural civil society. In short, social capital and indigenous villages have far-reaching gaps in talks about the similarities of characters used as social binders which are then capitalized on to create a new system. Indigenous village refers to the similarity of values embedded for a long time in society in specific social environments, thus, it refers to a concept of governance that internalizes the value of locality into the system. The basis of the analysis used in rural areas is the value of locality believed in an indigenous community which then becomes the norm of a governance system.

\section{Findings}

\section{Distortion of Governance: The Single Power of Ammatoa}

The Ammatoa is one of the indigenous communities that still exist in Indonesia. It is located in Tanah Toa village, Bulukumba Regency in South Sulawesi province. This community consists of approximately 4000 people with a leader called Ammatoa. In carrying out their daily activities, this community always upholds the principle of Pasang Ri Kajang which is the life philosophy of society (Akifah \& Mukrimin, 2012, p. 117). This rule contains philosophical values that characterize a society living in modesty (kamase-mase). The kamase-mase practice is reflected in the shape of a house made with similar models, size, and dressed in black. This belief was preserved for years to avoid any social jealousy between the people.

Tanah Toa village has a very exclusive system of government. The holder of supreme power is Ammatoa, who is believed to be the guardian of the universe and selected based on descendants. Under that belief, all the ethical issues relating to community affairs in Tanah Toa are fully submitted to Ammatoa. Meanwhile, to optimize the governance that takes place in this community, 24 Galla are inaugurated, each in charge of some issues, including Head of Kajang Sub-district.

Theoretically, governance is considered one of the prescriptions which firmly believe in the involvement of many actors. The assumption that chaos may occur in the internal government owing to development and community empowerment occurs because of limited resources, while on other aspects considerable demands 
continue to be made to the government. Therefore, the above issues should be immediately acted upon by distributing it to another party or to a sole executive for development affairs and community empowerment. This logic is believed to break down chaos for other parties' involvement which begins to open, and can contribute to problem-solving.

However, while maintaining a single authority, the role of the regulation remains under the control of the government. Conflicts in Tanah Toa however are usually in line with the prescription beliefs offered by critical thinking. In many cases, Ammatoa, as the highest indigenous leader, was shut down in order to involve many actors. In the field, the development and service activities are only conducted independently, without involving many parties to accommodate the private sector. The state is only present within certain limits in the field of fulfilling the administrative rights of indigenous people and some in the form of empowerment which is more for social assistance.

In the field, its presence was limited to complete the authority attached to Ammatoa as the sole power holder in Tanah Toa. The role of the state will be present in the community when the problems faced are genuinely beyond the means of completion, for instance in health. When its traditional ingredients can no longer cure the sufferer, then the country provides health services. This is carried out by first submitting a completed application with administrative files obtained by the state through its apparatus. During the study, a grandfather of over 50 years old suffering from acute mag illness for months was identified. The beliefs of most rural peoples is that such diseases must be cured locally through medication performed by a dukun (indigenous medical practitioner). However, for three months, the patient did not heal but became worse. When it became critical, they employed the services of the state government.

Another example is with the market (private sector) as the third actor of governance. In practice, the involvement of the private sector is limited and almost impossible, unlike the general public who depend solely on the produce of the market for their daily needs. The black cloth is preferred in dressing because bright colors are prohibited. Researchers and other visitors must wear black clothes. It turns out that the fabrics used are not imported or purchased from the market but are self-produced.

Meanwhile, for domestic affairs, all materials and tools used to build houses are sourced from nature. The bases and walls use wood from the forest while the roofs are lontar (dried palm leaves). This is a manifestation of the belief that nature is their source of life, while maintaining the excitement of the value of locality rejected by modernity. Similarly, electricity as one of the most critical needs was rejected because it is considered a product of modernization capable of ruining lives.

\section{Indigenous Governance Services of Ammatoa}

Like the general public, indigenes of Ammatoa communities also obtain the same services in terms of health insurance and primary education, the difference being the administrative requirements. The names listed in the healthcare unit differ from the identities used with the majority utilizing common names used in customary areas when submitting as beneficiaries of health insurance aid, 
and with differing ID cards. This issue is small but has a huge impact because the databases referring to recipients of healthcare from this community will be limited. However, healthcare workers tolerate the situation and also provide services. Almost all health care units face the same constraints, for instance in Kajang where two units also experienced similar inconsistencies when identifying people. In many places immunization services are always conducted in villages or hamlets, but in Ammatoa community it is carried out in early childhood and door to door by health workers. This is because some parents are too lazy to take their children out of customary areas.

Also, education services are treated differently in regards to people living in rural areas. In Bulukumba, there is a local regulation (Perda) that pays extraordinary attention to the sustainability of education. This regulation is then realized by providing special academic services to the villages of Tanah Toa. One of these was the establishment of 351 Ammatoa Primary School (SD 351) located at the entrance to the community.

In contrast to schools in most places, SD 351 is clear in its keeping with the value of Ammatoa's local customs. Students are generally prohibited from wearing red and white uniforms as in other schools. This is in harmony with their belief of not allowing the use of striking colors for every community in Tanah Toa. Instead, both students and teachers are expected to wear black, which is the hallmark of its customs.

Another aspect that differentiates is the type of lessons in SD 351. In addition to serving primary education with formal lessons, it also provides informal education. Schools provide informal classes for the Ammatoa indigenous people who have dropped out or have not been educated, with lessons geared more towards strengthening skills. In the community, the dropout rate is quite high with a yearly number of 30 people of between 10 and 12 years (fourth to sixth grade). This data does not include those over 12 years old, whose numbers are also not small. This rate cannot be separated from the conflicts and activities of these rural communities because to them, caring for nature is more important than anything else. This activity is realized from the activities of agriculture and gardening in primary and secondary school. Therefore, the majority of parents are more interested in agricultural products than having to send their children to school. Thus, there are times SD 351 loses dozens of learners and in one instance it was closed for two weeks. Long holidays also lower the motivation to learn, with some returning to school while others drop out.

Meanwhile, the schools do not have the power to prohibit learners from going on holiday. Many parents demanded their children be allowed to skip classes during the harvest period, but the school objected. This is linked to the increasing number of dropouts which has totaled about 200 learners with ages ranging from 12 to 19 by the end of 2017 .

Special treatment about the provision of indigenous governance services is also encountered on the given course content. As such, 351 students are required to optimize the potential of the customary forest. So the material is taught more as the provision of skills. One of these is embroidering threads into cloth. Teaching and learning processes are also increasingly thick with 
the nuances of custom by using the local language for communication. Its use facilitates the transfer of knowledge to learners compared to the Indonesian language. This is because most of the indigenous communities living in the Ammatoa area are isolated from the broader environment which creates limited interaction patterns.

The above case does not include the school initiated by one of the teachers of Islamic religious education in SD 351. According to this teacher, the basic knowledge of religion taught in the school has always clashed with the indigenous tradition of Ammatoa. For this set of people, religious learning has its rituals that must be passed on by cultural means. This is because according to adat belief, acquiring its knowledge can lead to insanity. Often students are rejected by parents who still hold firm adat beliefs from acquiring Islamic education owing to the fear of being cursed. The series of adat is meant as a form of ritual performed customarily in children who want to study religion such as the Koran, and even then they must pay attention to age.

\section{Discussion}

One way to establish a position in winning an indigenous village conflict is to create its own rule of law or, by another term, self-regulation. With this, all interests can be translated through legal rules that can be widely applicable to an indigenous community. In the concept of governance, self-regulation is one of three other analyses that make this concept unrelentingly criticized (De Angelis, 2005). Criticism of governance is the existence of space that can create self-regulation in the form of rules which go along with motives and encouragement for selfinterest or class. Even so, it is applicable to all, even if limited by the involvement of a few people.

In the context of the Ammatoa indigenous community, much of the current regulations continue to make it highly vulnerable to self-regulatory practice. This stems from cultural beliefs that all issues are based on adat rules. Although in the three rules are applied to the daily lives, the first comes from God, which is believed to be a value that should not be violated by anyone - god-sourced rules such as the prohibition of lies and to put forward honesty. The next is sourced from the state, regulating the way of life of a society which is mainly on the provisions of the government. Finally, the last comes from adat, which is a rule believed to live and grow in social life.

The practice of indigenous village governance in Tanah Toa village puts all the problems on adat, especially in disputes relating to customary forests. This can be seen from the legal framework believed by the people and comprising of three levels of law namely pokok bakbalak, tangnga bakbalak and cappa bakbalak which reflect the level of crime committed by the perpetrator. The first is a significant offence, for example, grabbing the land and cutting down trees in areas of customs. Sanctions are in the form of a fine of 12 million rupiah plus a roll of white cloth. The second punishes people for mediocre offences. This violation consists of undermining indigenous women, or when men and women are dating in the adat area. The penalty is a fine of eight real (traditional currency) or eight mil- 
lion rupiahs in addition to a buffalo. The last level also known as cappa bakbalak, a mild violation for example, being rude in a customary area. Violators are subject to a penalty of 6 million rupiahs.

These rules have been applied for generations where Ammatoa is a sacred person guarding the rule. This is included in determining Galla or Ammatoa's maid which is also based on customary law provisions, referring to the genealogical lineage reinforced by very religious instructions. However, in practice, again this was all decided by Ammatoa as part of the self-regulation of customs and which decisions cannot be rejected, including when lifting or lowering Galla. All decisions at the will of Ammatoa, no one dares to refuse let alone questions it because dialectical space is not allowed. Whenever questions arose, reasonable answers were provided by making customary rules as a shield over every decision. This narrative further reinforces Ammatoa's position as an indigenous leader by continuously reproducing the law as a part of self-regulation.

As self-regulation, it runs two functions at once which are a source and embodiment of the law itself. The position as a source of law is run when society is faced with a case that requires a decision such as a land dispute. Even as per the village head's confession, the community is more confident of Ammatoa's decision than the state law or the police, and this is applicable to other disputes. Generally, in Indonesia, theft cases are handled by the police with formal legal provision, however, the reverse is the case in this region.

For indigenous communities, incendiary events such as theft should be resolved through customary rules. In the village of Tanah Toa, this way is known as attunu panroli and it is a ceremony led by Ammatoa in an open field in the middle of the forest. All residents who live in the customs area must attend the ceremony which seeks justice and punishes through the holding of a hot iron that has been burning for hours. All the people in turn are invited to hold the hot iron while Ammatoa and all the indigenous people witness who are the perpetrators. The guilty feel the burning heat when they touch the iron whereas the innocent do not. This is just one of the self-regulatory portraits found in indigenous communities through Ammatoa becoming a legal source that survives to this day. Interestingly, self-regulation which, according to common sense, is out of control, is one way that continues to be preserved as a source of customary law that has not shifted from any other formal legal source. This set of people still uphold the source of the law that has been a tradition for many years.

While the position as the embodiment of the law itself is a consequence of the customary rule, the determination of this fate according to beliefs is final and can no longer be debated (Akifah \& Mukrimin, 2012, p. 117). The position of Ammatoa as a traditional leader derived from heredity due to the will of customary rules also makes it a form of customary law itself. However, subsequent rumors to the public from the self-regulation practice that took place about the motive of interest are implied by adat rules. This is because the separation of interests is getting thinner and robust. Moreover, custom law products are only decided on a limited basis by Ammatoa and the Galla with the provisions that apply to the customary law. Generally, there is limited space, only the socialization of customary law. 


\section{Conclusion}

The results showed that the village of Tanah Toa run the governance with the value of locality, especially on three aspects. Firstly, indigenous government actors involved only in civil society groups while at the same time neglecting partners such as markets and countries. Secondly, the process in providing services to the community is more exclusive, isolated and not integrated with modern governance systems. Third, the rule in the village is a regulation that comes from the community's belief.

This case can more broadly conclude that the sustainability of indigenous village governance is a matter of the existence of customary law including all values of indigenous locality, which in some contexts characterizes the existence of indigenous people. In many places in Indonesia such as Tanah Toa, it is not merely a matter of social identity. Moreover, indigenous law is the driving force of the governance system that takes place in indigenous people.

Conflicts of Interest: The authors declare no conflict of interest.

\section{REFERENCES}

1. Akifah, A., Mukrimin \& Kajang (2012). Kajang, A Picture of Modesty: An Indonesian Local Belief. Al-Ulum, vol. 12, no 1, pp. 117-128.

2. Antlöv, H., Wetterberg, A. \& Dharmawan, L. (2016). Village Governance, Community Life, and the 2014 Village Law in Indonesia. Bulletin of Indonesian Economic Studies, vol. 52, no 2, pp. 161-183. Available at: https://doi.org/10.1080/00074918.2015.1129047 (accessed: 20 August, 2019).

3. Asrinaldi (2017). Power Network of Penghulu Adat in the Concurrent Regional Election in West Sumatera. Jurnal Ilmu Sosial dan Ilmu Politik, vol. 21, no 1, pp. 57-73. Available at: https://doi.org/10.22146/jsp.28701 (accessed: 20 August, 2019).

4. Von Benda-Beckmann, F. \& Von Benda-Beckmann, K. (2010). Multiple Embeddedness and Systemic Implications: Struggles over Natural Resources in Minangkabau since the Reformasi. Asian Journal of Social Science, vol. 38, no 2, pp. 172-186. Available at: https://doi.org/ 10.1163/156853110X490881(accessed: 20 August, 2019).

5. Carroll, T. (2009). 'Social Development' as Neoliberal Trojan Horse: The World Bank and the Kecamatan Development Program in Indonesia. Development and Change, vol. 40, no 3, pp. 447-466. Available at: https://doi.org/10.1111/j.1467-7660.2009.01561.x (accessed: 20 August, 2019).

6. De Angelis, M. (2005). The Political Economy of Global Neoliberal Governance. Review (Fernand Braudel Center), vol. 28, no 3, pp. 229-257.

7. Djaha, A.S.A. \& Lake, P. (2018). The Structure Design of Customary Village: A Case Study in Probur Village, Alor Regency of Indonesia. Russian Journal of Agricultural and Socio-Economic Sciences, vol. 75, no 3, pp. 117-124. Available at: https://doi.org/10.18551/ rjoas.2018-03.13 (accessed: 24 September, 2019).

8. Field, J. (2017). Social Capital. 3rd Edition. Routledge, Taylor \& Francis Group, London New York. 
9. Haryanto (2017). Adaptation and Continuities in Clientelism in a Fishing Community in Takalar, South Sulawesi. Contemporary Southeast Asia, vol. 39, no 3, pp. 511-531. Available at: https://doi.org/10.1355/cs39-3f (accessed: 24 September, 2019).

10. Hidayat, Y., Febriyanto, I.I. \& Nadzir, M.H. (2017). Transformasi dan Dualisme Kelembagaan dalam Pemerintah Adat Minang: Studi terhadap Nagari Pariangan, Sumatera Barat. Politik Indonesia: Indonesian Political Science Review, vol. 2, no 2, pp. 227-245. Available at: https:// doi.org/10.15294/jpi.v2i2.9021 (accessed: 24 September, 2019).

11. Humaeni, A. (2014). Penggunaan Magic dalam Politik Lokal di Banten. Masyarakat, Kebudayaan dan Politik, vol. 27, no 1, pp. 14-26. Available at: https://doi.org/10.20473/mkp. V27I12014.14-26 (accessed: 24 September, 2019).

12. Kurniawan, R.C. (2017). Piil Pesenggiri: A Concept of Political Power in Lampung Culture. Jurnal Ilmu Sosial dan Ilmu Politik, vol. 21, no 1, pp. 74-86. Available at: https://doi. org/10.22146/jsp.28702 (accessed: 24 September, 2019).

13. Pamungkas, C. (2017). The Campaign of Papua Peace Network for Papua Peace Land. Jurnal Ilmu Sosial dan Ilmu Politik, vol. 21, no 2, pp. 147-159. Available at: https://doi.org/10.22146/ jsp.30440 (accessed: 24 September, 2019).

14. Salim, A., Bulan, W.R., Untung, B., Laksono, I. \& Brock, K. (2017). Indonesia's Village Law: Enabler or Constraint for More Accountable Governance? IDS, Brighton.

15. Sastrawati, N. (2017). Gaukang and White Coup: Dismantling of Traditional Power. Jurnal Ilmu Sosial dan Ilmu Politik, vol. 21, no 2, pp. 160-172. Available at: https://doi.org/10.22146/ jsp.30442 (accessed: 24 September, 2019).

16. Steenbergen, D.J. (2016). Strategic Customary Village Leadership in the Context of Marine Conservation and Development in Southeast Maluku, Indonesia. Human Ecology, vol. 44, no 3, pp. 311-327. Available at: https://doi.org/10.1007/s10745-016-9829-6 (accessed: 24 September, 2019).

17. Sukmawati, Utaya, S. \& Susilo, S. (2015). The Local Wisdom of Indigenous People on Forest Preservation as Learning Source of Geographic Subject. Jurnal Pendidikan Humaniora, vol. 3 , no 3, pp. 202-208.

18. Surtikanti, H.K., Syulasmi, A. \& Ramdhani, N. (2017). Traditional Knowledge of Local Wisdom of Ammatoa Kajang Tribe (South Sulawesi) about Environmental Conservation. Journal of Physics: Conference Series 895, 012122. Available at: https://doi.org/10.1088/17426596/895/1/012122 (accessed: 24 September, 2019).

19. Susan, N. \& Budirahayu, T. (2018). Village Government Capacity in the Implementation of Village Law No. 6 of 2015 in Indonesia. In: McLellan, B. (Ed.). Sustainable Future for Human Security. Springer Singapore, Singapore, pp. 17-27. Available at: https://doi.org/10.1007/978981-10-5433-4_2 (accessed: 24 September, 2019).

20. Syarif, E., Fatchan, A., Sumarmi \& Astina, K. (2016). Tradition of "Pasang Ri-Kajang" in the Forests Managing in System Mores of "Ammatoa" at District Bulukumba South Sulawesi, Indonesia. Mediterranean Journal of Social Sciences, vol. 7, no 6, pp. 325-332. Available at: https://doi.org/10.5901/mjss.2016.v7n6p325 (accessed: 24 September, 2019).

21. Tyson, A. (2011). Being Special, Becoming Indigenous: Dilemmas of Special Adat Rights in Indonesia. Asian Journal of Social Science, vol. 39, no 5, pp. 652-673. Available at: https:// doi.org/10.1163/156853111X608339 (accessed: 24 September, 2019). 